
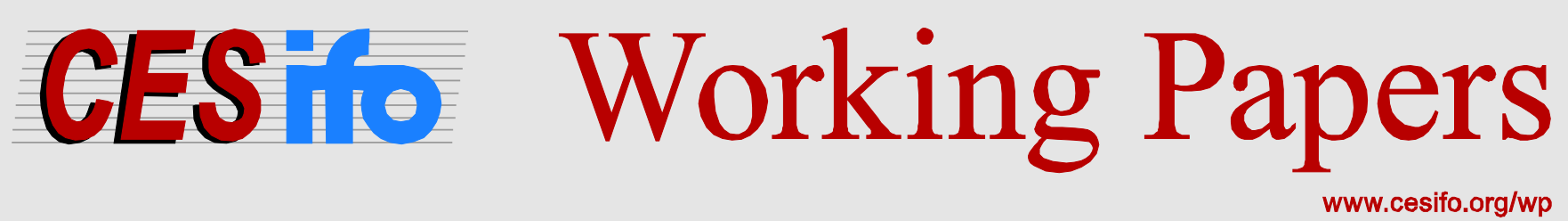

\title{
Frederick Jackson Turner and the Westward Expanse: Changing Net Nutrition with Economic Development
}

\author{
Scott Alan Carson
}

CESIFO WORKING PAPER NO. 5869

CATEGORY 4: LABOUR MARKETS

APRIL 2016

An electronic version of the paper may be downloaded

- from the SSRN website:

- from the RePEc website:

- from the CESifo website:

wWw.SSRN.com

www.RePEc.org

www.CESifo-group.org/wp 


\title{
Frederick Jackson Turner and the Westward Expanse: Changing Net Nutrition with Economic Development
}

\begin{abstract}
A population's average stature reflects its cumulative net nutrition and provides important insight when more traditional measures for economic well-being is scarce or unreliable. Heights on the US Central Plains did not experience the antebellum paradox experienced in Eastern urban areas, and statures increased markedly in the late 19th and early 20th centuries. Known for offering migrants economic opportunity, the Central Plains received migrant in-flows from Northern, Southern, and Eastern Europe, and US statures were the tallest in the World. Within the US, individuals from the South were taller than individuals from the North, East, and West. Whites were taller than blacks on the Central Plains where slavery was not the primary labor force, but whites were also taller than blacks in the American South where it was. Immigrants from industrialized Europe were shorter than black and white Americans but taller than Latin Americans and Asians.
\end{abstract}

JEL-Codes: I100, J110, J710, N310.

Keywords: nineteenth century black and white stature variation, urbanization, US Central Plains.

Scott Alan Carson

University of Texas, Permian Basin

4901 East University

USA - Odessa, TX 79762

Carson_S@utpb.edu

I appreciate comments from John Komlos, Lee Carson, and Paul Hodges. Shahil Sharma, Chinuedu Akah, Meekam Okeke, Ryan Keifer, Tiffany Grant, Bryce Harper, Greg Davis, and Paul Hodges. I appreciate research support from Kellye Manning. 


\section{Frederick Jackson Turner and the Westward Expanse: Changing Net Nutrition with Economic Development}

\section{Introduction}

In 1893, Frederick Jackson Turner proposed that America’s Far Western frontier served as an economic 'safety valve,' a place where immigrants could move from the eastern US and Europe to escape the rigid economic conditions that crystalized against their upward economic mobility. During the $19^{\text {th }}$ century, US agricultural output and economic development varied regionally, and regions that are agriculturally productive in the $21^{\text {st }}$ century are not the same as those in the $19^{\text {th }}$ century (Ransom and Sutch, 1977, p. 151; Cochrane, 1979, pp. 24-32, 69-77). Health and statures are related to economic development, socioeconomic status, and occupations, and much of the Plains’ economic advantage was associated with fertile farmlands, nutritious diets, and sparse population densities (Komlos, 1987; Haines, Weiss, and Craig, 2003; Carson, 2012). Both the South and Plains had fertile soils; however, labor market arrangements varied between the two regions. Long hostage to slavery, much of the South's labor force was bound and not free to migrate or acquire the human capital that is present among free populations. The result was that with slavery’s demise, the South’s agricultural efficiencies were eliminated, and the Central Plains became the most productive US agricultural region (Irwin, 1994; Fogel and Engerman, 1974, pp. 236 and 238; Fogel, 1989; Ransom and Sutch, 1977, p. 151). This study, therefore, uses black and white stature variation on the Central Plains to show that male statures 
increased with the US transition a free labor force, and agricultural development to offer an economic safety valve to urbanization and industrialization.

The use of height to measure cumulative net nutrition is now a well-accepted methodology in economics and development studies (Fogel, 1994; Case and Paxson, 2008; Deaton, 2008) and reflects the difference between nutrition, disease exposure, and physical activity (Fogel et al., 1978; Komlos, 1985; Komlos, 1987; Komlos, 1989; Floud et al., 2011). There is a complex relationship between heights and genetics, and in developed economies, 80 percent of height is determined by genetics, while stature in developing economies is only 60 percent determined by genetics (Luke et al. 2001, Siventoinen, 2003, pp. 266-271). By considering average versus individual stature, genetic differences are mitigated, leaving only the influence of the economic and physical environments on stature. When diets, health, and physical environments improve, average stature increases and decreases when diets become less nutritious, disease environments deteriorate, or the physical environment places more stress on the body. In sum, stature provides important insight into understanding historical processes and augments other $19^{\text {th }}$ century welfare measures when other measurements are not available.

It is against this backdrop that this study considers three paths of inquiry into late $19^{\text {th }}$ and early $20^{\text {th }}$ century black and white stature variation on the US Central Plains. First, as multiple nationalities streamed westward, how did $19^{\text {th }}$ century statures vary overtime on the Central Plains? Statures increased with the development of large-scale farming and increasing agricultural productivity, indicating that, like material conditions, net nutrition and biological conditions on the Central Plains improved with economic development. Second, how did black and white statures vary by nativity? Rural Southerners were taller than urban Northeasterners, who were shorter than from elsewhere within the US. Third, how did statures vary by 
occupations in this rapidly developing Plains economy? Throughout the late $19^{\text {th }}$ and early $20^{\text {th }}$ centuries, rural environments were beneficial for human growth, and farmers and ranchers in close proximity to nutritious diets were taller than their counterparts in other occupations.

\section{Nineteenth Century Plains Immigration and Agricultural Development}

An important region during US economic development, little is known about how statures varied on the $19^{\text {th }}$ century Central Plains. Between 1840 and 1860 , the Plains received many British, German, and Irish immigrants, and British and German migrants were more likely than the Irish to move to the US interior (Ferrie, 1999, pp. 39-70). This willingness to migrate and assimilate was associated with economic opportunity, and the British and Germans experienced greater economic mobility and wealth accumulation than Irish migrants who remained in Eastern States. Between 1890 and 1915, the source of migration changed, and in the late $19^{\text {th }}$ and early $20^{\text {th }}$ centuries, the Plains received many Southern and Eastern Europeans (Cohn, 2013, pp. 206-207).

A binding constraint on late $19^{\text {th }}$ and early $20^{\text {th }}$ century agriculture was labor, and labor in-flows on the Central Plains were insufficient to accommodate the economic growth necessary to improve living conditions. The impetus that sent agricultural productivity forward was technological change (Cochrane, 1979, pp. 189-202), and the first of the great agricultural innovations in the late 1830s were John Deere’s plow and Cyrus McCormack’s reaper. Other $19^{\text {th }}$ century agricultural innovations included disks, harrowers, corn-planters, mowers, and hay making equipment (Olmstead and Rhode, 1995; Olmstead and Rhode, 2008). The Civil War created an even greater need for labor saving devices, and after 1865, improvements in agriculture came more from adopting existing labor saving technologies than new agricultural innovations. Moreover, hauling plows and heavy farm equipment was demanding on $19^{\text {th }}$ 
century draft animals, and required mechanization for agriculture to fully develop. The last of the major $19^{\text {th }}$ century agricultural innovations was the gasoline powered tractor, and by 1910 , tractors were integrated into Plains’ agricultural production (Cochrane, 1979, pp. 108-109). By the 1930s, corn hybridization became common, and farmers in Plains states adapted these technologies more readily than in other US regions (Griliches, 1971, p. 208).

The Mississippi River is the largest North American river system. Originating in northern Minnesota, it flows southward for 2,530 miles to the Mississippi River Delta, and a medley of tributaries from the Rocky and Appalachian Mountains drain parts of 31 states and two Canadian provinces into the Mississippi River. The Missouri River is also one of North America's largest river systems and drains nearly one sixth of the water from the continent. Originating in Montana’s western Rockies, the Missouri River flows eastward for 2,341 miles across Montana, Wyoming, Colorado, the Dakotas, and Nebraska before draining into the Mississippi River just north of Saint Louis, Missouri. Originally used by indigenous cultures to transport goods and peoples, the Mississippi and Missouri Rivers were the mainstay for more prolific agricultural societies. When Europeans arrived in the $16^{\text {th }}$ century, traffic on the Mississippi and Missouri Rivers increased, and immigrants used the Mississippi and Missouri river systems as low cost transportation routes to penetrate Central North America, making these watersheds integral parts of the Central Plains economic development.

Economic development and urbanization can be hazardous to health, and populations in Europe and North America experienced stature declines during periods when economic development changed rapidly. The process is complex, but a few factors are associated with urban stature decline: rapid population growth without adequate improvement in public sanitation; transportation and commercial revolutions; changing disease environments; and 
growing populations that depend on wage income (Haines, 2004, p. 249; Zhetmayer, 2011;

Zhetmayer, 2013). The Central Plains were also important in $19^{\text {th }}$ century economic development, because while it remained mostly rural, there were rapidly growing urban centers, such as Saint Louis. Between 1850 and 1870, Saint Louis's population grew by 306\%. The growth rate slowed after 1860, but between 1870 and 1920, Saint Louis’ populations increased by 186\% (Carter, et al., 2006, p. 1-140). In sum, economic opportunity attracted many immigrants to the Central Plains and was associated with economic growth; however, when populations concentrated in urban locations, this early growth was associated with health hazards and deteriorating net nutrition.

\section{Nineteenth Century Plains Prison Data}

North America's Central Plains is the broad expanse of grass-covered prairie that lies west of the Great Lakes and east of the Rocky Mountains. Data used to study statures on the Central Plains is a subset of a large $19^{\text {th }}$ century prison sample. All available US state repositories were contacted, and available records were entered into a comprehensive data set. These records include Arizona, California, Colorado, Idaho, Kentucky, Maryland, Mississippi, Missouri, Montana, Nebraska, New Mexico, Ohio, Oregon, Pennsylvania, Tennessee, Texas, Utah, and Washington. To determine how male statures varied on the Central Plains, observations from the Colorado, Illinois, Missouri, Montana, and Nebraska prisons are included in this study. Between 1800 and 1920, prison officials routinely recorded dates inmates were received, age, complexion, stature, pre-incarceration occupation, and nativity. Physical descriptions were recorded as a means of identification by prison enumerators at the time of incarceration in the case an inmate escaped and was later recaptured; therefore, physical descriptions reflect pre-incarceration conditions. 
All historical height data have various biases, and the two most common sources of $19^{\text {th }}$ century heights are military and prison samples. While plentiful, one potential problem with military heights is a truncation bias created by minimum stature requirements for service (Sokoloff and Villaflor, 1982). Like military data, the prison data is not random, but the type of incarceration criteria prison records contain may have their own advantages, such as being drawn from lower social groups, that segment of society more vulnerable to economic change. The prison data are, however, not without limitations, and it is not clear which segment of society prison records represent. For example, law enforcement officials may have incarcerated shorter individuals who were in poor health that resorted to crime out of privation. Alternatively, law enforcement officials may have targeted taller individuals if they stereotyped them as guilty because taller individuals used physical stature to take advantage of their shorter counterparts. Arrests across states may have resulted in various selection biases that may affect the results of this investigation. However, prison stature variation is consistent with other stature studies (Komlos, 1992; Komlos and Coclanis, 1997; Sunder, 2004). By including all crimes, this concern is reduced, and there is little systematic evidence that physical size or body mass were related with crimes committed (Carson, 2005, p. 414; Carson, 2007, p. 44). ${ }^{1}$

Prison enumerators recorded a complexion variable, from which ethnicity is inferred. African-Americans were recorded as light black, mulatto, medium black, copper, and dark black. Whites were recorded as white, light, medium, fair, and dark. While individuals of African and European ancestry were referred to as 'mulattos' in both prisons and the US census until the 1930s, they are referenced to as ‘mixed-race’ throughout this study (Bodenhorn, 2015, p. 5).

\footnotetext{
${ }^{1}$ Floud et al. (2011. p. 331) present average stature estimates for $19^{\text {th }}$ century males. Their stature estimates are only .5 percent taller than individuals in prison.
} 
Whereas mixed-race inmates had genetic characteristics common to both African and European populations, they were treated as blacks in the $19^{\text {th }}$ century US and are grouped here with other black inmates. The most common complexion in the Central Plains was white, followed by blacks and mixed-race. Other ethnic groups include Latin Americans, Native Americans, and Asians.

Occupations are an important measure that represent socioeconomic status and are classified here into seven categories. Highly skilled physicians and government administrators are classified as white collar workers. Craft workers, blacksmiths, and light manufacturers are classified as skilled workers. General farmers are classified as farmers. Ranchers lived in rural agricultural areas in close proximity to animal proteins and benefited from a protein-rich diet. There were also laborers designated in the prison records. Farm laborers and ranch hands are classified as farm laborers, while miners, laborers, and cooks are classified as unskilled workers. Some workers were also recorded as not having an occupation, which includes workers who recorded "none” or "no occupation" as their trade. 
Table 1, Nineteenth Century Plains Ages, Birth Periods Nativity, and Occupations

\begin{tabular}{|c|c|c|c|c|c|c|c|c|c|}
\hline & $N$ & $\%$ & Cent & S.D. & & $N$ & $\%$ & Cent & S.D. \\
\hline Ages & & & & & Nativity & & & & \\
\hline Teens & 11,153 & 10.60 & 169.45 & 6.75 & Northeast & 2,194 & 2.09 & 170.90 & 6.68 \\
\hline $20 \mathrm{~s}$ & 53,493 & 50.84 & 171.40 & 6.65 & $\begin{array}{l}\text { Middle } \\
\text { Atlantic }\end{array}$ & 11,511 & 10.94 & 170.80 & 6.35 \\
\hline $30 s$ & 24,415 & 23.21 & 171.65 & 6.66 & Great Lakes & 22,175 & 21.08 & 171.73 & 6.46 \\
\hline $40 \mathrm{~s}$ & 10,554 & 10.03 & 171.19 & 6.71 & Plains & 31,159 & 29.62 & 171.67 & 6.70 \\
\hline $50 \mathrm{~s}$ & 4,118 & 3.91 & 170.69 & 6.73 & Southeast & 13,536 & 12.87 & 171.68 & 6.83 \\
\hline $60 \mathrm{~s}$ & 1,267 & 1.20 & 169.97 & 6.94 & Southwest & 2,648 & 2.52 & 172.04 & 7.10 \\
\hline $70 \mathrm{~s}$ & 212 & .20 & 169.87 & 6.57 & Far West & 3,654 & 3.47 & 172.46 & 6.70 \\
\hline $\begin{array}{l}\text { Birth } \\
\text { Decade }\end{array}$ & & & & & Africa & 56 & .05 & 168.94 & 6.61 \\
\hline $1800 s$ & 273 & .26 & 170.33 & 6.61 & Asia & 148 & .14 & 164.10 & 8.38 \\
\hline $1810 \mathrm{~s}$ & 862 & .82 & 170.46 & 6.65 & Australia & 101 & .10 & 169.83 & 6.13 \\
\hline $1820 s$ & 2,029 & 1.93 & 170.69 & 7.17 & Canada & 2,051 & 1.95 & 170.81 & 6.84 \\
\hline $1830 \mathrm{~s}$ & 4,618 & 4.39 & 170.76 & 6.81 & Europe & 9,100 & 8.65 & 168.86 & 6.66 \\
\hline $1840 \mathrm{~s}$ & 10,430 & 9.91 & 170.83 & 6.70 & $\begin{array}{l}\text { Great } \\
\text { Britain }\end{array}$ & 5,862 & 5.57 & 169.63 & 6.52 \\
\hline $1850 \mathrm{~s}$ & 15,805 & 15.02 & 170.65 & 6.70 & $\begin{array}{l}\text { Latin } \\
\text { America }\end{array}$ & 132 & .13 & 169.92 & 6.96 \\
\hline $1860 s$ & 14,715 & 13.99 & 171.18 & 6.52 & Mexico & 885 & .84 & 167.01 & 6.67 \\
\hline $1870 s$ & 19,369 & 18.41 & 171.21 & 6.61 & Occupations & & & & \\
\hline $1880 \mathrm{~s}$ & 19,419 & 18.46 & 171.25 & 6.69 & $\begin{array}{l}\text { White- } \\
\text { Collar }\end{array}$ & 12,535 & 11.91 & 171.17 & 6.48 \\
\hline $1890 \mathrm{~s}$ & 12,737 & 12.11 & 171.43 & 6.77 & Skilled & 25,748 & 24.47 & 171.11 & 6.58 \\
\hline $1900 \mathrm{~s}$ & 3,604 & 3.43 & 172.69 & 6.80 & Farmer & 12,430 & 11.81 & 172.47 & 6.65 \\
\hline $1910 \mathrm{~s}$ & 1,193 & 1.13 & 175.05 & 6.36 & Rancher & 1,075 & 1.02 & 173.31 & 6.81 \\
\hline $1920 s$ & 158 & .15 & 176.39 & 6.76 & Farm Labor & 434 & .41 & 173.62 & 6.25 \\
\hline Ethnic & & & & & $\begin{array}{l}\text { Unskilled } \\
\text { No } \\
\text { Occupations }\end{array}$ & $\begin{array}{c}47,920 \\
5,070\end{array}$ & $\begin{array}{c}45.55 \\
4.82\end{array}$ & $\begin{array}{l}170.90 \\
170.37\end{array}$ & $\begin{array}{l}6.76 \\
7.00\end{array}$ \\
\hline White & 87,025 & 82.71 & 171.50 & 6.63 & Total & 105,212 & 100.00 & 171.18 & 6.71 \\
\hline Black & 13,177 & 12.52 & 169.59 & 6.80 & & & & & \\
\hline Mixed-race & 4,170 & 3.96 & 170.07 & 6.89 & & & & & \\
\hline $\begin{array}{l}\text { Native- } \\
\text { American }\end{array}$ & 293 & .28 & 173.16 & 6.44 & & & & & \\
\hline Asian & 54 & .05 & 162.71 & 6.36 & & & & & \\
\hline Mexican & 493 & .47 & 166.20 & 6.36 & & & & & \\
\hline
\end{tabular}

Source: Colorado State Archives, 1313 Sherman, Denver Colorado; Missouri State Archives, 600 West

Main St., Jefferson City, Missouri, 65102; Montana Historical Society, 225 North Roberts St., Helena, Montana, 59620; Nebraska State Historical Society, 1500 R Street, Lincoln, NE 68501; New 
Mexico State Records Center and Archives, 1205 Camino Carlos Rey, Santa Fe, New Mexico, 87507.

White ethnicity was more common than black, and there are Latin Americans, NativeAmericans, and Asian populations in the sample (Table 1). The greatest concentration of whites was in Montana, and the greatest concentration of blacks was in Missouri. Because migrants remained on latitudinal trajectories, most nativities on the Central Plains were from Plains and Great Lakes states (Steckel, 1983; Steckel, 1986). Smaller populations were from the Northeast and Southwest. Most international immigrants were from Europe-especially Germany, Ireland and later Italy_-while other immigrants were from Britain and Canada (Cohn, 2013, pp. 206207). The most common occupations were unskilled and skilled workers, and there were several workers from agricultural occupations (Carson, 2009, p. 153). Like today, prisoners were younger, and most prisoner birth decades were between the 1860s and 1880s (Hirschi and Gottfredson, 1983; Carson, 2009). Reflecting time necessary to reach maturity and migrate to the US, foreign born men were incarcerated at older ages; US-born individuals were incarcerated at younger ages (Table 2). The US had only recently been settled, and most individuals born in the early $19^{\text {th }}$ century were foreign born, while most US-born men were incarcerated in the late $19^{\text {th }}$ century. The foreign-born were more likely to be white-collar and unskilled workers, while US-born men were more likely to be farmers or farm laborers. 
Table 2, Nineteenth Century Ages, Birth Periods, and Occupations by Birth

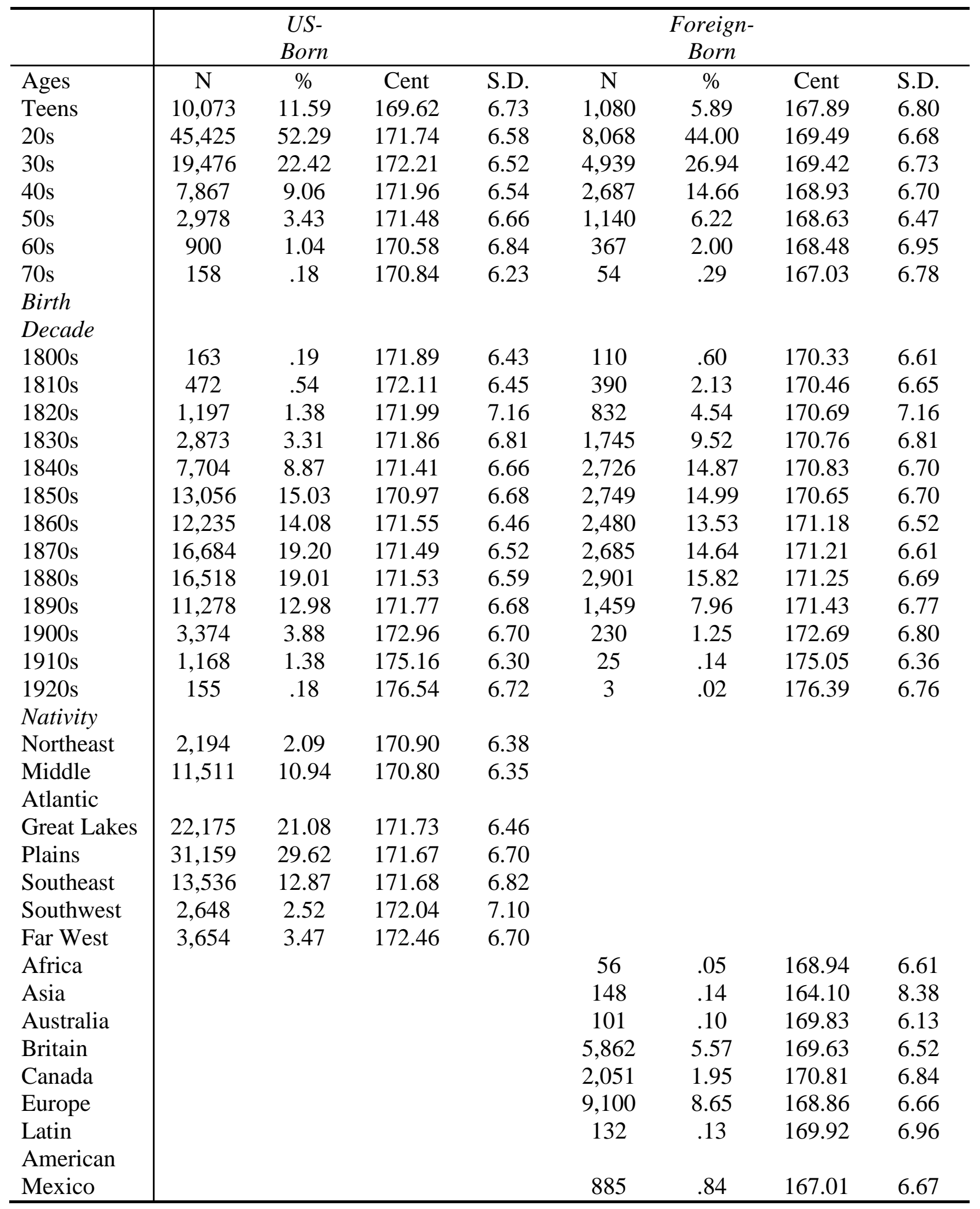




\begin{tabular}{l|cccccccc}
\hline $\begin{array}{l}\text { Occupations } \\
\text { White- }\end{array}$ & 9,943 & 11.44 & 171.34 & 6.42 & 2,592 & 14.14 & 169.40 & 6.41 \\
Collar & & & & & & & & \\
Skilled & 20,717 & 23.85 & 171.60 & 6.45 & 5,031 & 27.44 & 169.07 & 6.70 \\
Ranchers & 903 & 1.04 & 173.83 & 6.63 & 172 & .94 & 170.59 & 7.13 \\
Farmers & 11,184 & 12.87 & 172.74 & 6.57 & 1,246 & 6.80 & 170.06 & 6.88 \\
Farm & 356 & .41 & 173.96 & 6.40 & 78 & .43 & 172.04 & 5.24 \\
Laborers & & & & & & & & \\
Unskilled & 39,981 & 46.02 & 171.26 & 6.70 & 7,939 & 43.30 & 169.11 & 6.80 \\
No & 3,793 & 4.37 & 170.88 & 7.08 & 1,277 & 6.96 & 168.85 & 6.54 \\
Occupation & & & & & & & & \\
Total & 86,877 & 100.00 & 171.60 & 6.63 & 18,335 & 100.00 & 169.21 & 6.71 \\
\hline
\end{tabular}

Source: See Table 1.

\section{The Effects of Demographics, Socioeconomics Status, and Residence with Black} and White Stature Variation on the Central Plains

The timing and extent of stature variation depends on ethnicity, demographics, birth period, nativity, and occupations. These variables are now tested with least squares regression models to assess how characteristics were associated with $19^{\text {th }}$ century stature variation on the US Central Plains. To start, individuals are partitioned into total, black, white, US born, and foreign born samples.

$$
\begin{gathered}
\text { Centimeters }_{i}=\alpha++_{i}+\sum_{r=1}^{4} \beta_{r} \text { Ethnicity }_{i}+\sum_{a=1}^{15} \beta_{a} \text { Age }_{i}+\sum_{t=1}^{13} \beta_{t} \text { Birth Period }_{i}+ \\
\sum_{n=1}^{11} \beta_{n} \text { Nativity }_{i}+\sum_{i=1}^{6} \beta_{l} \text { Occupations }_{i}+\varepsilon_{i}
\end{gathered}
$$

Ethnic dummy variables are included to determine how statures varied with skin complexion, and age dummy variables are included to assess how Plains' youth statures increased between ages 15 through 22; 10 year adult age dummy variables are included for ages 40 through 70 (Huang et al., 2013). Because stature varies considerably over the life-course, age 
dummy variables are included because they impose less rigid constraints on the relationship between height and age. To measure how statures varied with economic development, birth decade dummy variables are included for birth between 1800 and 1920 . Stature is sensitive to the physical environment, and nativity dummy variables are included to account for the relationship between cumulative net nutrition and the physical environment in which a person came to maturity. Individual white-collar, skilled, rancher, agricultural workers, and unskilled laborer occupation dummy variables are included to measure how statures varied by socioeconomic status.

To assess the relationship between stature and skin complexion, black, mixed-race, Native-American, Latin American, and Asian dummy variables are included in model 1. Model 2 accounts for US-born black stature variation, while Model 3 does the same for whites. To isolate how statures varied with US nativity, the sample is restricted in Model 4 to only US births and to non-US births in Model 5. Because there are few females, only males are included in Models 1 through 5. However, the stature of women on the Plains is combined with other women in the US in other studies (Carson, 2011; Carson, 2013a). 
Table 3, Nineteenth Century Plains Statures by Ethnicity, Demographics, and Occupations

\begin{tabular}{|c|c|c|c|c|c|}
\hline & Model 1 & Model 2 & Model 3 & Model 4 & Model 5 \\
\hline & Total & Black & White & US Born & Non-US Born \\
\hline Intercept & $173.71^{* * *}$ & $172.43 * * *$ & $173.46 * * *$ & $173.97 * * *$ & $169.57 * * *$ \\
\hline \multicolumn{6}{|l|}{ Ethnicity } \\
\hline White & Reference & & & Reference & Reference \\
\hline Black & $-2.51 * * *$ & Reference & & $-2.56 * * * 43 * *$ & -.364 \\
\hline Mixed-race & $-1.77 * * *$ & $.841 * * *$ & & $-1.78 * * *$ & $-1.92 * *$ \\
\hline Native & .584 & & & & \\
\hline \multicolumn{6}{|l|}{ American } \\
\hline Asian & $-3.91 * *$ & & & & \\
\hline Latin & $-4.35 * * *$ & & & & \\
\hline \multicolumn{6}{|l|}{ Ages } \\
\hline 15 & $-8.45 * * *$ & $-10.07^{* * *}$ & $-7.55 * * *$ & $-8.66 * * *$ & $-7.07 * * *$ \\
\hline 16 & $-4.50 * * *$ & $-4.32 * * *$ & $-4.76 * * *$ & $-4.60 * * *$ & $-4.74 * * *$ \\
\hline 17 & $-3.36 * * *$ & $-3.61 * * *$ & $-3.51 * * *$ & $-3.54 * * *$ & $-2.78 * * *$ \\
\hline 18 & $-2.02 * * *$ & $-2.48 * * *$ & $-2.02 * * *$ & $-2.21 * * *$ & $-1.41 * * *$ \\
\hline 19 & $-1.16 * * *$ & $-1.57 * * *$ & $-1.20 * * *$ & $-1.30 * * *$ & $-1.09 * * *$ \\
\hline 20 & $-.577 * * *$ & $-1.01 * * *$ & $-.681 * * *$ & $-.749 * * *$ & $-.121 *$ \\
\hline 21 & $-.256 * * *$ & $-.802 * * *$ & $-.318 * *$ & $-.418 * * *$ & $-.112 *$ \\
\hline 22 & $-.181 * * *$ & $-.647 * * *$ & $-.241 *$ & $-.330 * * *$ & .008 \\
\hline $23-39$ & Reference & Reference & Reference & Reference & Reference \\
\hline $40 \mathrm{~s}$ & -.120 & -.182 & .021 & -.016 & $-.421 * * *$ \\
\hline $50 \mathrm{~s}$ & $-.561 * * *$ & $-.791 * * *$ & $-.495 * * *$ & $-.545 * * *$ & $-.616 * * *$ \\
\hline $60 s$ & $-1.21 * * *$ & $-1.29 * * *$ & $-1.43 * * *$ & $-1.44 * * *$ & $-.689 * * *$ \\
\hline $70 \mathrm{~s}$ & $-1.27 * * *$ & -.070 & $-1.45 * * *$ & $-1.23 * * *$ & $-1.89 * * *$ \\
\hline \multicolumn{6}{|l|}{ Birth Year } \\
\hline $1800 s$ & $-1.43 * *$ & .428 & -.897 & -.749 & $-2.07 *$ \\
\hline $1810 \mathrm{~s}$ & $-1.33 * * *$ & $-2.35 *$ & -.456 & -.738 & $-1.69 * *$ \\
\hline $1820 s$ & $-1.34 * * *$ & $-2.61 * * *$ & $-.730 *$ & $-1.01 * *$ & $-1.40 *$ \\
\hline 1830s & $-1.52 * * *$ & $-1.76 * * *$ & $-1.16 * * *$ & $-1.31 * * *$ & $-1.54 * *$ \\
\hline $1840 \mathrm{~s}$ & $-1.58 * * *$ & $-2.33 * * *$ & $-1.41 * * *$ & $-1.58 * * *$ & $-1.29 *$ \\
\hline $1850 \mathrm{~s}$ & $-1.63 * * *$ & $-2.12 * * *$ & $-1.58 * * *$ & $-1.70 * * *$ & -1.14 \\
\hline 1860s & $-1.27 * * *$ & $-1.73 * * *$ & $-1.19 * *$ & $-1.30 * * *$ & -.932 \\
\hline 1870s & $-1.32 * * *$ & $-1.55 * * *$ & $-1.37 * * *$ & $-1.39 * * *$ & -.817 \\
\hline 1880s & $-1.27 * * *$ & $-1.88 * * *$ & $-1.25 * * *$ & $-1.38 * * *$ & -.467 \\
\hline 1890s & $-1.08 * * *$ & $-1.72 * * *$ & $-.989 * * *$ & $-1.12 * * *$ & -.571 \\
\hline $1900 \mathrm{~s}$ & Reference & Reference & Reference & Reference & Reference \\
\hline $1910 \mathrm{~s}$ & $1.77 * * *$ & $1.88 * *$ & $1.78 * * *$ & $1.80 * * *$ & .847 \\
\hline $1920 s$ & $3.74 * * *$ & $3.74^{* *}$ & $3.89 * * *$ & $3.91 * * *$ & -1.50 \\
\hline \multicolumn{6}{|l|}{ Nativity } \\
\hline Northeast & $-1.42 * * *$ & $-1.21 * * *$ & $-1.28 * * *$ & $-1.58 * * *$ & \\
\hline Middle & $-1.48 * * *$ & $-1.85 * * *$ & $-1.32 * * *$ & $-1.64 * * *$ & \\
\hline \multicolumn{6}{|l|}{ Atlantic } \\
\hline Great Lakes & $-.625 * * *$ & $-1.17 * * *$ & $-.411 * * *$ & $-.750 * * *$ & \\
\hline
\end{tabular}




\begin{tabular}{|c|c|c|c|c|c|}
\hline Plains & $-.430 * * *$ & $-1.68 * * *$ & -.046 & $-.533 * * *$ & \\
\hline Southeast & .130 & $-.772 * * *$ & $.291 *$ & -.014 & \\
\hline Southwest & Reference & Reference & Reference & Reference & \\
\hline Far West & -.047 & -.678 & .238 & -.105 & \\
\hline Africa & $-3.00 * * *$ & & & & Reference \\
\hline Asia & $-6.56 * * *$ & & & & $-3.36 * * *$ \\
\hline Australia & $-2.33^{* *}$ & & & & .935 \\
\hline Britain & $-2.72 * * *$ & & & & .975 \\
\hline Canada & $-1.55 * * *$ & & & & $1.87 * *$ \\
\hline Europe & $-3.70 * * *$ & & & & -.147 \\
\hline Latin & $-1.56 * *$ & & & & 1.20 \\
\hline America & & & & & \\
\hline Mexico & $-4.29 * * *$ & & & & $-1.71^{*}$ \\
\hline Occupations & & & & & \\
\hline White-Collar & .166 & .776 & .094 & .124 & .410 \\
\hline Skilled & .182 & .630 & .222 & .237 & .037 \\
\hline Ranchers & $1.83 * * *$ & .308 & $2.04 * * *$ & $1.96 * * *$ & $1.42 *$ \\
\hline Farmers & $1.26 * * *$ & $2.15 * * *$ & $1.44 * * *$ & $1.29 * * *$ & $1.38 * * *$ \\
\hline $\begin{array}{l}\text { Farm } \\
\text { Laborers }\end{array}$ & $2.88 * * *$ & $5.18 * *$ & $2.89 * * *$ & $3.02 * * *$ & $2.97 * *$ \\
\hline Unskilled & $.288 * *$ & .635 & $.375^{*}$ & $.342 *$ & .180 \\
\hline No & Reference & Reference & Reference & Reference & Reference \\
\hline Occupation & & & & & \\
\hline $\mathrm{N}$ & 105,212 & 16,922 & 69,497 & 86,419 & 17,953 \\
\hline $\mathrm{R}^{2}$ & .0663 & .0449 & .0337 & .0531 & .0264 \\
\hline
\end{tabular}

Source: See Table 1.

Notes: Models estimated with least squares and White robust standard errors. 
Three patterns emerge when comparing how statures varied on the Central Plains with demographic characteristics, socioeconomic status, and nativity. First, the antebellum paradox is the proposition that US heights declined during the $19^{\text {th }}$ century's second and third quarters at the same time that income and wealth increased (Fogel et al., 1978; Komlos, 1987; Fogel, 1994; Steckel and Haurin, 1994, p. 124; Fogel, 2000, pp. 139-142). Moreover, Frederick Jackson Turner hypothesized in 1893 that when economic and social conditions crystalized in eastern states and Europe that the Plains and Far West served as a 'safety valve' for economic development because settlers could move west in search of opportunity. However, this view has recently been challenged Libecap and Hansen (2002) and Hansen and Libecap, (2004), who maintain that Central Plains’ material conditions decreased with economic development when settlers were slow to respond to information asymmetries regarding the weather and slow to change their crop mixes, agricultural techniques, and farm sizes (Libecap and Hansen, 2002; Hansen and Libecap 2004; Libecap and Hansen, 2004). However, black and white statures on the Central Plains increased after the Civil War, indicating that rather than a region of biological stress created by economic development and imperfect information, statures on the Central Plains increased with agricultural and economic development (Figure 1; Stewart, 2006; Stewart, 2009, pp. 261-264). Moreover, there is little evidence of the anti-bellum paradox, which is expected given that the Central Plains during the mid- $19^{\text {th }}$ century did not experience wide-scale urbanization and the corresponding increase in the relative price of food (Komlos, 1987, p. 915; Carson, 2008a, pp. 366-368). Therefore, black and white working class statures on the Central Plains may not have experienced the antebellum paradox to the same degree as in other regions, and the post-Civil War stature increase indicates that rather than an area of economic and 
geographic net nutritional stress, conditions on the Central Plains improved with economic development.

Figure 1, Nineteenth Century Central Plains Stature

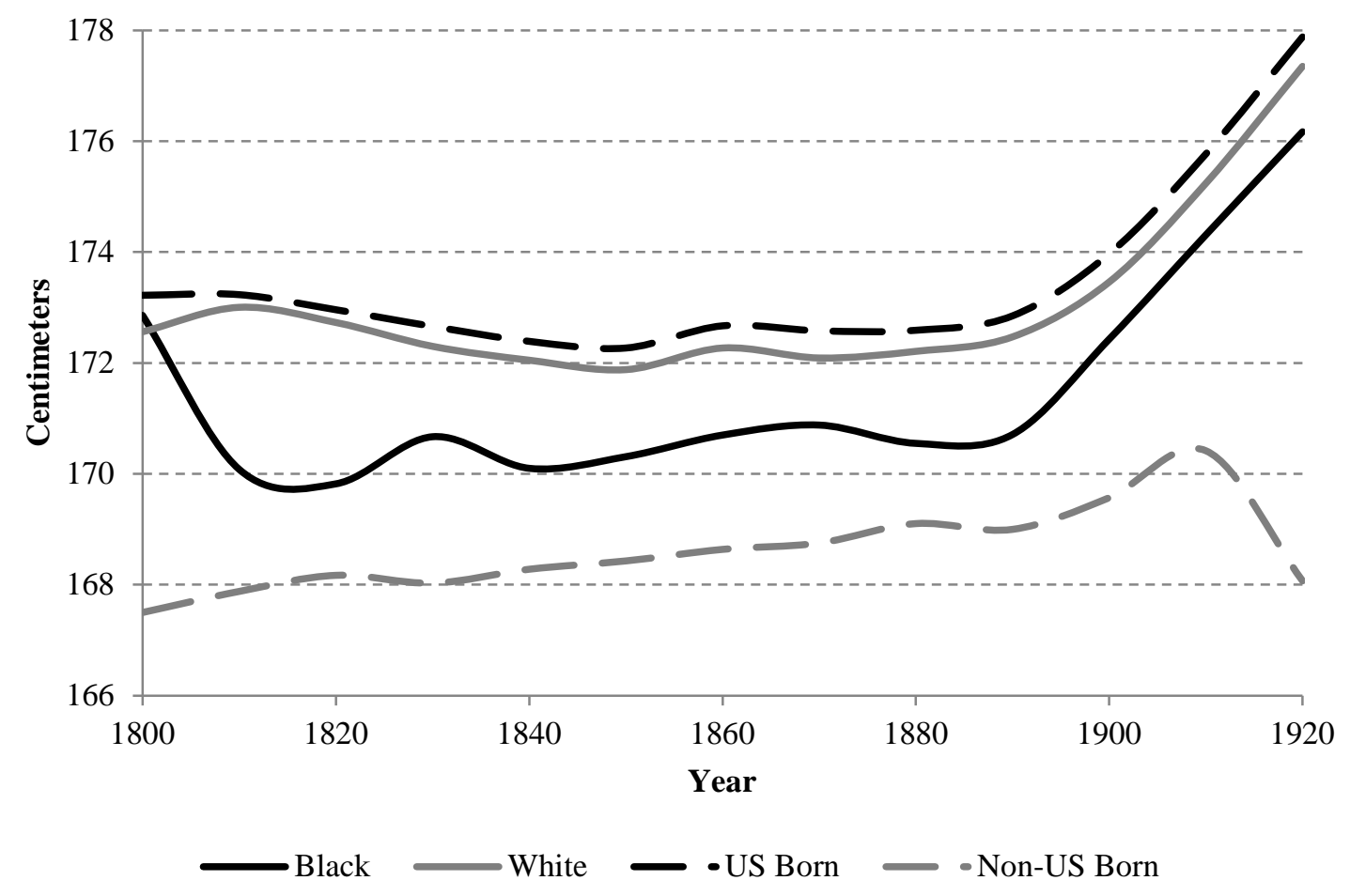

Source: See Table 2.

Second, statures also varied by nativity and individuals born on the Central Plains were among the tallest international populations. Prince and Steckel (2003, p. 369) find an inverted U-shaped height by latitude gradient for white Union Army recruits and Plains’ Native Americans and attribute the pattern to spatial differences in diets, work effort, and disease. This Plain's height by latitude gradient across Native, African, and European Americans indicates that biological conditions by geography had a significant role in $19^{\text {th }}$ century stature variation and economic development. Moreover, individuals born in the South but who migrated north to the 
Central Plains had the tallest US statures (Steckel and Haurin, 1994; Carson, 2009; Zahetmeyer, 2011, p. 6). Before the Civil War and emancipation, the South was self-sufficient in food production and a geographic area that was sparsely populated (Ransom and Sutch, 1977, p. 150; Carson, 2009a, p. 151; Carson, 2012). However, after the War, Southern agriculture productivity decreased, and the South became a net food importer (Ransom and Sutch, 1977, pp. 150-155). On the other hand, individuals born in Middle Atlantic and Northeastern states were shorter because these regions had greater population densities and were separated from agricultural production, which increased the relative price of nutrition (Komlos, 1987, Table 8, p. 909; Carson, 2008c, pp. 366-368; Carson, 2010, p. 475). Stature is also related to population density, and the $19^{\text {th }}$ century South was more rural than Middle Atlantic and Northeastern states. Statures increased in states with low population densities and reached a maximum in states with population densities of 42 persons per square mile, which is approximately equal to Illinois’ population density (Carson, 2009c, p. 51; Carson, 2010, p. 475).

The $19^{\text {th }}$ century Central Plains received many international immigrants, and Canadians who migrated south were the tallest international migrants on the Central Plains. During the $19^{\text {th }}$ century, Canadian-born statures remained constant or decreased slightly, despite increasing income (Cranfield and Inwood, 2007, pp. 212-216). British-born immigrants were shorter than Canadians but were taller than Continental Europeans, and $19^{\text {th }}$ century Europeans encountered some of the dreadful net nutritional conditions within what was then the developing world (Floud et al., 2011). Latin Americans on the Central Plains were among the shortest ethnic groups (Lopez-Alonzo, 2003; Carson, 2005, pp. 413-415). However, the shortest ethnic group was Asians, and short and decreasing Chinese sojourn workers indicates that net nutritional conditions in Southeast Asia decreased with the Opium Wars and Taiping Rebellion (Morgan, 
2004, p. 206; Carson, 2005; Carson, 2007, pp. 178-181). In sum, international nativity on the Plains confirms other nativity patterns, and Southern black and white Americans had the tallest statures, while their counterparts from rapidly industrializing Europe and underdeveloped Latin America and Asia were considerably shorter.

Third, statures were also related to occupations and socioeconomic status, and ranchers, who were in close proximity to animal proteins, amino acids, and dairy products, were taller than workers in other occupations (Komlos, 1987; Carson, 2008b; Silventoinen, 2003). Rural agricultural farmers, who lived in close proximity to agricultural output and mild disease environments, were also taller than workers in workers other occupations. Moreover, whitecollar and skilled workers were urbanized and faced relatively high food prices and were shorter than workers in other occupations (Komlos, 1987; Carson, 2009, p. 155; Komlos, 1998). On the other hand, non-agricultural unskilled laborers on the Central Plains were shorter than workers in other occupations and indicate that unskilled laborers’ working-class conditions were associated with inferior net nutrition. Because many $19^{\text {th }}$ century prison enumerators failed to distinguish between unskilled and agricultural laborers, the omission likely over-estimates the benefits of being an unskilled laborer and under-estimates the benefits of being a farm laborer (Carson, 2011; Carson, 2013b).

Other patterns are consistent with expectations. A common finding in historical and contemporary studies is that fairer complexioned individuals are taller than their darker complexioned counterparts, and an early interpretation for this stature difference was Southern social preferences that disproportionately favored fairer to darker complexioned blacks. ${ }^{2}$

\footnotetext{
${ }^{2}$ Modern black and white statures are comparable when brought to maturity under optimal biological conditions (Eveleth and Tanner, 1976; Tanner, 1977; Steckel 1995, p. 1910; Barondess et al., 1997, p. 968; Komlos and Baur,
} 
However, if fairer complexioned mixed-race individuals on the Plains were taller than darker complexioned blacks, it indicates Southern social prejudice may not account for fairer complexioned individuals because slavery was not prominent on the Northern Plains. Whites and mixed-race individuals were taller than blacks in all regions within the $19^{\text {th }}$ century US, which indicates that Southern social prefaces by skin complexion as the sole explanation for height differences does not account for the black-white stature differential (Table 3). There are other reasons why $19^{\text {th }}$ century whites were taller than blacks. Whites had greater access to meat and better nutrition (Margo and Steckel, 1982, pp. 514-515, 517, and 519), and up to 40 percent of stature variation in developing economies is due to environmental conditions. Blacks also did not consume as many dairy products as whites (Hilliard, 1972; Kiple and King, 1981, pp. 83-85; Carson, 2008c), and milk consumption is positively related with stature growth (Wiley, 2005, pp. 432-440). Two other complexion patterns on the Central Plains are consistent with the existing literature. Native-American statures were comparable to white statures (Steckel and Prince, 2001; Komlos, 2003), and Latin American and Asian statures were shorter than other populations (Morgan, 2004; Carson, 2005; Carson, 2007).

\section{Explaining the Difference between Plains White and Black Stature Differences}

To more fully account for the Central Plains white-black stature differential, a BlinderOaxaca decomposition is constructed for white and black statures (Oaxaca, 1973). A BlinderOaxaca decomposition is a statistical procedure used to detect labor market discrimination but is also used to distinguish between dependent variable differences that are due to average characteristics and returns to characteristics. Let $\mathrm{S}_{\mathrm{w}}$ and $\mathrm{S}_{\mathrm{b}}$ represent the statures of whites and

2004, pp. 64 and 69; Nelson et al., 1993, pp. 18-20; Godoy et al. 2005, pp. 472-473; Margo and Steckel, 1982, p. 519). 
blacks, respectively; $\alpha_{\mathrm{w}}$ and $\alpha_{\mathrm{b}}$ are the autonomous stature components that accrue to whites and blacks; $\beta_{\mathrm{w}}$ and $\beta_{\mathrm{b}}$ are returns associated with specific stature enhancing characteristics, such as age and occupation. $\mathrm{X}_{\mathrm{w}}$ and $\mathrm{X}_{\mathrm{b}}$ are black and white average characteristic matrices, and whites are assumed to be the base structure.

$$
\begin{array}{ll}
\text { White stature function: } & \mathrm{S}_{\mathrm{w}}=\alpha_{w}+\beta_{w} X_{w} \\
\text { Black stature function: } & \mathrm{S}_{\mathrm{b}}=\alpha_{b}+\beta_{b} X_{b}
\end{array}
$$

The white and black stature gap is the difference between white and black statures.

$$
\Delta S=S_{w}-S_{b}=\alpha_{w}+\beta_{w} X_{w}-\alpha_{b}-\beta_{b} X_{b}
$$

Adding and subtracting $\beta_{\mathrm{w}} \mathrm{X}_{\mathrm{b}}$ to the right hand side of the equation and collecting like terms leads to

$$
\Delta S=S_{w}-S_{b}=\left(\alpha_{w}-\alpha_{b}\right)+\left(\beta_{w}-\beta_{b}\right) X_{w}+\beta_{b}\left(X_{w}-X_{b}\right)
$$

The first right-hand side element, $\left(\alpha_{w}-\alpha_{b}\right)$, is the part of the stature differential due to non-identifiable sources, such as better access to nutrition that favored whites. The second right hand-side element, $\left(\beta_{w}-\beta_{b}\right)$, is the component of the stature differential due to characteristic returns. The third right-hand side element, $\left(\bar{X}_{w}-\bar{X}_{b}\right)$, is the part of the stature differential due to differences in average characteristics. 
Table 4, Central Plains Black and White Stature Decompositions

\begin{tabular}{l|cccc}
\hline Levels & $\left(\beta_{w}-\beta_{b}\right) \bar{X}_{b}$ & $\left(\bar{X}_{w}-\bar{X}_{b}\right) \beta_{w}$ & $\left(\beta_{w}-\beta_{b}\right) \bar{X}_{w}$ & $\left(\bar{X}_{w}-\bar{X}_{b}\right) \beta_{b}$ \\
\hline & Returns to & Mean & Returns to & Mean \\
Characteristics & Characteristics & Characteristics & Characteristics \\
Sum & 2.59 & -.073 & 2.34 & .177 \\
Total & & 2.52 & & 2.52 \\
Proportions & & & & \\
Intercept & .409 & & .409 & .054 \\
Ages & .058 & .054 & .054 & .009 \\
Birth Decade & .206 & .021 & .217 & -.042 \\
Nativity & .487 & -.128 & .402 & .045 \\
Occupations & -.131 & .024 & -.152 & .070 \\
Sum & 1.03 & -.029 & .930 & 1 \\
Total & & 1 & & \\
\hline
\end{tabular}

Source: See Tables 1 and 2.

Using coefficients from stature regressions (Table 3, Models 2 and 3), the white-black stature decomposition indicates taller white statures were due to unobservable characteristics in the intercept, such as better nutrition that accrued to whites. Figure 1 illustrates that after 1860, black stature increases were greater than for whites. The net cumulative rate of stature returns increased more for blacks than for whites, indicating that black cumulative net nutritional returns increases were greater for blacks than whites on the Central Plains; however, the majority of the white-black stature differential is explained by non-identifiable characteristics, such as differences in white and black access to cumulative net nutrition.

\section{Conclusion}

In 1893, Frederick Jackson Turner proposed that America’s Far Western frontier was a 'safety-valve' against the economic stress associated with industrialization and urbanization. Despite recent challengers to the safety value hypothesis, Jackson's hypothesis with respect to 
statures on the Central Plains cannot be rejected and is robust to recent criticism. The late $19^{\text {th }}$ and early $20^{\text {th }}$ century US Central Plains was a dynamic region during a period of considerable economic change associated with high mass immigration and market development. Central Plains' stature variation over the late $19^{\text {th }}$ and early $20^{\text {th }}$ century indicates that rather than an area of stagnation and decline, net cumulative nutrition on the Central Plains improved considerably with economic development. Individuals on the late $19^{\text {th }}$ and early $20^{\text {th }}$ century Central Plains were taller than other international nativities, in part because they were in close proximity to greater net nutrition and faced lower relative food prices; the development of large-scale farming created an environment where biological conditions on the Central Plains improved with economic development. Statures were also related to rural western environments, and individuals in states with population densities approximately equal to those in Illinois reached the tallest statures. Proximity to nutritious diets was associated with taller statures, and ranchers and farmers were taller than workers in other occupations. Therefore, statures on the Central Plains illustrate that rather than a time and place of economic and nutritional stagnation, net nutrition improved with economic development in this largely rural agricultural region. 


\section{References}

Atack, Jeremy, Bateman, Fred, and William Parker (2000). “The Farm, the Farmer, and the Market” In Engerman, Stanley and Robert Gallman (eds.) Cambridge Economic History of the United States, Vol. 2 Cambridge: Cambridge University Press, 245-284.

Barondess, D. A. Nelson, D A., \& Schlaen, S. E., (1997) “Whole Body Bone, Fat and Lean Mass in Black and White Men,” Journal of Bone and Mineral Research, 12, 967-971.

Bodernhorn, H. (2015). The Color Factor: The Economics of African-American Well Beingt in the Nineteenth Century South. Oxford: Oxford University Press.

Carson, Scott Alan. (2005) “The Biological Standard of Living in 19th-Century Mexico and in the American West,” Economics and Human Biology, Volume 3(3), 405-419.

Carson, Scott Alan. (2007) “Mexican Body Mass Index Values in the $19^{\text {th }}$ Century American West,” Economics and Human Biology, Volume, 5(1), 37-47.

Carson, Scott Alan. (2008a) "Health during Industrialization: Evidence from the $19^{\text {th }}$ Century Pennsylvania State Prison System,” Social Science History. Volume 32(3). pp. 347-372.

Carson, Scott Alan. (2008b) "Health during Industrialization: Additional Evidence from the $19^{\text {th }}$ Century Missouri State Prison System,” Journal of BioSocial Science. 40(4), pp. 587605.

Carson, Scott Alan. (2008c) "The Effect of Geography and Vitamin D on African-American Stature in the $19^{\text {th }}$ Century: Evidence from Prison Records,” Journal of Economic History, 68(3), pp. 812-830. 
Carson, Scott Alan, (2009a) "Geography, Insolation and Vitamin D in 19th Century US AfricanAmerican and White Statures,” Explorations in Economic History. 46(1), pp. 149-159.

Carson, Scott Alan. (2009b) “African-American and White Inequality in the $19^{\text {th }}$ Century American South: A Biological Comparison,” 22(3), Journal of Population Economics. pp. $757-772$.

Carson, Scott Alan, (2009c) "Health, Wealth and Inequality: a Contribution to the Debate about the relationship between Inequality and Health,” 42(4), Historical Methods. pp. 43-56.

Carson, Scott Alan. (2010a), “Wealth, Inequality, and Insolation Effects across the $19^{\text {th }}$ Century White US Stature Distribution,” Journal Homo of Comparative Human Biology, 61, pp. 467-478.

Carson, Scott Alan, (2010b), “Institutional Change, Geography, and Insolation in $19^{\text {th }}$ Century African-American and White Statures in Southern States,” Journal of Economic Issues 44(3). pp. 737-756.

Carson, Scott Alan. (2011), "Height of Female Americans in the $19^{\text {th }}$ century and the Antebellum Puzzle,” Economics and Human Biology 9, pp. 157-164.

Carson, Scott Alan. (2012). "Family Size, the Physical Environment, and Socioeconomic Effects Across the Stature Distribution.” Journal Homo of Comparative Human Biology. 63(2).

Carson, Scott Alan. (2013a). "Socioeconomic Effects on the Stature of Nineteenth Century US Women.” Feminist Economics 19, pp. 122-143.

Carson, Scott Alan (2013b). "Biological Conditions and Economic Development: Westward Expansion and Health in Late Nineteenth and Early Twentieth Century Montana.” Journal of the Historical Society, 13(1): 51-68. 
Carson, Scott Alan. (2014). “Institutional Change and $19^{\text {th }}$ Century Southern Black and White BMI Variation." Journal of Institutional and Theoretical Economics 170 (2), pp. 296316.

Carter, Susan B., Scott Sigmund Gartner, Michael Haines, Alan Olmstead, Richard Sutch, and Gavin Wright. 2006. Historical Statistics of the United States, Millennial Edition.

Volume 1. Cambridge University Press: Cambridge.

Case, Ann and Christina Paxson. "Height, Health, and Cognitive Function at Older Ages.” American Economic Review 98, 3 (May 2008): 463-467.

Cochrane, Willard (1979). The Development of American Agriculture. University of Minnesota Press: Minneapolis.

Cohn, Raymond. (2013). “The Economic History of Immigration.” In: Robert Whaples and Richard E. Parker. Rougledge: New York, pp. 265-276.

Cohn, Raymond (2009). Mass Migration Under Sail: European Immigration to the Antebellum United States. Cambridge University Press: Cambridge.

Cranfild, J. and K. Inwood. 2007. “The Great Transformation: A Long-Run Perspective on Physical Well-Being in Canada.” Economics and Human Biology 5(2), pp. 204-228.

Deaton, Angus. “Height, Health, and Inequality: The Distribution of Adult Heights in India.” American Economic Review 98, 2 (May 2008): 468-474.

Etcheson, Nichole. (2004). Bleeding Kansas: Contested Liberty in the Civil War Era. Lawrence: University of Kansas Press.

Eveleth, Phillis B. and James M. Tanner. Worldwide Variation in Human Growth. Cambridge: Cambridge University Press. 1976. Second Ed. 1990.

Ferrie, Joseph P. (1999). Yankeys Now: Immigrants in the Antebellum U.S. 1840-1860. Oxford: 
Oxford University Press.

Ferrie, Joseph and Werner Troesken. (2008) “Water and Chicago’s Mortality Transition, 1850-1925.” Explorations in Economic History 45, pp. 1-16.

Floud, Roderick (1994) "Introduction: Growth in height as a mirror of the standard of living.” in John Komlos (ed.) Stature, Living Standards, and Economic Development. Chicago: University of Chicago Press.

Floud, Roderick, Robert Fogel, Bernard Harris, and Sok Chil Hong (2011) The changing body: Health, nutrition, and human development world since 1700 . Cambridge: Cambridge University Press.

Fogel, Robert W. (1989). Without Consent or Contract: The Rise and Fall of American Slavery. W.W. Norton. New York.

Fogel, Robert W. "Economic Growth, Population Theory and Physiology: The Bearing of Long-Term Processes on the Making of Economic Policy,” American Economic Review 84(3), 1994, pp. 369-395.

Fogel, Robert William. (2000). The Fourth Great Awakening \& The Future of Egalitarianism. Chicago: University of Chicago Press.

Fogel, Robert W. and Stanley Engerman, (1974). Time on the Cross. New York: W. W. Norton.

Fogel, Robert, Stanley L. Engerman, James Trussell, Rodrick Floud, Clayne Pope, and Larry Wimmer. 1978. "The Economics of Mortality in North American, 1650-1910: A Description of a Research Project.” Historical Methods 11(2), pp. 75-109.

Godoy, R., Goodman, E., Levins, R., \& Leonard, W.R. (2005) “Anthropometric Variability in the USA,” Annals of Human Biology 32, pp. 469-485. 
Green, Rayna. 2012. “Public Histories of Food.” In Jeffrey Pilcher (Ed.) The Oxford Handbook of Food History. Oxford: Oxford University Press. pp. 81-98.

Griliches, Zvi. (1971). “Hybrid Corn and the Economics of Innovation.” In Robert Fogel and Stan Engerman. The Reinterpretation of American Economic History. Harper Row Publishers. New York. pp. 207-213.

Haines, Michael. (2004). “Growing Incomes, Shrinking People-Can Economic Development Be Hazardous to Your Health?” Social Science History 28(2), pp. 249-270.

Haines, Michael, Lee Craig and Thomas Weiss. "The Short and the Dead: Nutrition, Mortality and the “Antebellum Puzzle in the United States,” Journal of Economic History 63, no. 2, (June 2003): 382-413.

Hansen Zeynep and Gary Libecap (2004). “Small Farms, Externalities, and the Dust Bowl of the 1930s.” Journal of Political Economy 112(3): 665-694.

Hirshchi, Travis and Michaeal Gottfredson. (1983). “Age and Explanation of Crime.” American Journal of Sociology 89(3), pp. 552-584.

Huang, Wei, Xiaoyan Lei, Geert Ridder, John Strauss, and Yaohui Zhao. (2013). "Health, Height, Height Shrinkage, and SES at Older Age: evidence from China.” American Economic Journal: Applied Economics, 5(2): 86-121.

Irwin, James R. (1994). “Explaining the Decline in Southern per Capita Output after Emancipations.” Explorations in Economic History 31, 3, pp. 336-356.

Kiple, Kenneth and Virginia King. 1981. Another Dimesion of the Black Diaspora: Diet, Disease, and Racism. Cambridge: Cambridge University Press.

Komlos, John. 1985. "Stature and Nutrition in the Hapsburg Monarchy: the Standard of Living and Economic Development in the Eighteenth Century.” American Historical Review 
90(5) 1149-1161.

Komlos, J., 1987. “The Height and Weight of West Point Cadets: Dietary Change in Antebellum America.” Journal of Economic History 47, 897-927.

Komlos, John. “Toward an Anthropometric History of African-Americans: The Case of the Free Blacks in Antebellum Maryland.” in Strategic Factors in Nineteenth Century American Economic History: A Volume to Honor Robert W. Fogel, edited by Claudia Goldin and Hugh Rockoff. Chicago: University of Chicago Press. 1992, 297-329.

Komlos, John. (2003). "Access to Food and the Biological Standard of Living: Perspectives on the Nutritional Status of Native Americans". American Economic Review 91 (1): 252255.

Komlos, John and Marieluise Baur, "From Tallest to (one of) the Fattest: the Enigmatic Fate of American Population in the $20^{\text {th }}$ Century.” Economics and Human Biology 2, no. 1 (March, 2004): 57-74.

Komlos, John and Peter Coclanis. “On the Puzzling Cycle in the Biological Standard of Living: The Case of Antebellum Georgia.” Explorations in Economic History. 34, no. 4 (October, 1997): 433-59.

Libcap, Gary and Zeynep Hansen. (2002) “'Rain Follows the Plow’ and Dry Farm Doctrine: the Climate Information Problem and Homestead Failure in the Upper Great Plains, 18901925.” Journal of Economic History, 62: 86-120.

Libecap, Gary and Zeynep Hansen (2004) “The allocation of property rights to land:

U.S. land policy and farm failure in the Great Plains.” Explorations in Economic History 62: 86-120.

Lopez-Alonso, M. and R.P. Condey. 2003. “The Ups and Downs of Mexican Economic Growth: 
the Biological Standard of Living in Inequality, 1870-1950.” Economics and Human Biology 1(2), pp. 169-186.

Margo, R., and Steckel, R. (1992) 'The nutrition and health of slaves and antebellum southern whites', in R.W. Fogel and S. Engerman (ed.) Without Consent or Contract: Conditions of Slave Life and the Transition to Freedom, New York: W.W. Norton.

Morgan, Stephen L. (2004). "Economic Growth and the Biological Standard of Living in China.” Economics and Human Biology 2(2), pp. 197-218.

Nelson, D., Kleerekoper, M., Peterson E. \& A. M. Parfitt, (1993) "Skin Color and Body Size as Risk Factors for Osteoporosis,” Osteoporosis International, 3, 18-23.

Oaxaca Ron L. "Male Female Wage Differentials in Urban Labor Markets." International Economic Review 14, 3 (October 1973): 693-709.

Olmstead, Alan and Paul Rhode (1995). "Beyond the Threshold: An Analysis of the Characteristics and Behavior of Early Reaper Adopters.” Journal of Economic History 55, pp. 27-57.

Olmstead, Alan and Paul Rhode (2008). Creating Abundance: Biological Innovation and American Agricultural Development. New York: Cambridge University Press.

Prince, Joseph and Richard Steckel 2003. "Nutritional Success on the Great Plains: NineteenthCentury Equestrian Nomads.” Journal of Interdisciplinary 33(3) pp. 353-384.

Ransom Roger and Richard Sutch. One Kind of Freedom: the Economic Consequences of Emancipation. Cambridge: Cambridge University Press, 1977.

Silventoinen, Karri. 2003. “Determinants of Variation in Adult Body Weight.” Journal of Biosocial Science 35. pp. 263-285. 
Sokoloff, K. \& Villaflor, G. (1982) “Early Achievement of Modern Stature in America,” Social Science History 6, 453-481.

Steckel, Richard. “Slave Height Profiles from Coastwise Manifests.” Explorations in Economic History 16 (1979): 363-380.

Steckel, Richard (1983) “Height and Per Capita Income,” Historical Methods, 16: 1-7.

Steckel, Richard, 1986 “A Peculiar Population: the Nutrition, Health and Mortality of American Slaves from Childhood through Mortality,” Journal of Economic History, 46, pp. 721-41.

Steckel, Richard H. (1990). "Poverty and Prosperity: A Longitudinal Study of Wealth Accumulation, 1850-1860," Review of Economics and Statistics, 72: 275-285.

Steckel, R.H. \& Haurin, D. (1994) “Health and Nutrition in the American Midwest: Evidence from the Height of Ohio National Guardsman 1850-1910.” In: Komlos, J. (Ed.), Stature, Living Standards and Economic Development. University Press of Chicago, Chicago, 117-128.

Steckel, Richard and Joseph Prince. 2001. “Tallest in the World: Native Americans on the Great Plains the Nineteenth Century.” American Economic Review. 91(1), pp. 287-294.

Stewart, James I. (2009), “Economic Opportunity or Hardship? The Causes of Geographic Mobility on the Agricultural Frontier, 1860-1880” Journal of Economic History 69, pp. 238-268.

Stewart, James I.(2006). "Migration to the Agricultural Frontier and Wealth Accumulation, 1860-1870,” Explorations in Economic History.

Sunder, Marco (2004) “The Height of Tennessee Convicts: Another Pieces of the "Antebellum Puzzle”. Economics and Human Biology. pp. 75-86. 
Tanner, James M, 1977, “Human Growth and Constitution,” in Harrison, GA, Weiner, JS, Tanner, JM, and Barnicot, NA (eds) Human Biology: an Introduction to Human Evolution, Variation, Growth and Ecology. pp. 301-384.

Turner, Frederick Jackson. 1893. “The Frontier in American History.” Proceedings of the State Historical Society of Wisconsin.

Wiley, Andrea S. (2005). “Does Milk Make Children Grow? Relationships between Milk Consumption and Height in NHANES 1999-2002.” American Journal of Human Biology 17: 425-441.

Zehetmayer, Matthias. (2011). “The Continuation of the Antebellum Puzzle: Stature in the US, 1847-1894.” European Review of Economic History. 